\title{
Writing Attitudes of Iranian EFL Students: A Qualitative Study
}

\author{
Razieh Gholaminejad \\ Faculty of Foreign Languages, University of Isfahan, Isfahan, Iran \\ Ahmad Moinzadeh \\ Faculty of Foreign Languages, University of Isfahan, Isfahan, Iran \\ Manijeh Youhanaee \\ Faculty of Foreign Languages, University of Isfahan, Isfahan, Iran \\ Hamidreza Ghobadirad \\ Faculty of Foreign Languages, University of Isfahan, Isfahan, Iran
}

\begin{abstract}
This paper reports on one aspect of a qualitative study conducted in an EFL setting, of the perception of writing attitudes of $65 \mathrm{EFL}$ students in the University of Isfahan. An open-ended questionnaire was administered to 65 undergraduates to examine firstly what the Iranian EFL students' attitudes towards writing in general are; secondly, whether Iranian EFL students are active writers, If yes, in which language; thirdly, whether Iranian EFL students feel any difference between expressing ideas while writing in English and Persian.
\end{abstract}

Index Terms - writing, attitude, active writer

\section{INTRODUCTION}

\section{A. What Is Writing?}

Writing is the expression of feelings, thoughts, desires and plans in black and white (Akkaya \& Kirmiz, 2010). Writing is a way to explore thoughts and ideas to make them evident and accessible. It is a difficult skill for both native and nonnative speakers in a similar way, because any writers should make a harmony among several issues such as content, organization, purpose, audience, vocabulary, punctuation, spelling, and mechanics (Hamed Jahin \& Wafa Idrees, 2012).

When thought is written down, ideas can be scrutinized, reassessed, rearranged, and changed, hence, it is fair to say that writing encourages deep thinking (Hamed Jahin \& Wafa Idrees, 2012).

Ranging from "mechanical control to creativity, with good grammar, knowledge of subject matter, awareness of stylistic conventions and various mysterious factors in between" (Wall, 1981, p.53), writing is regarded as a difficult, intricate and demanding skill to master (Graham, Harris \& Mason, 2005). In order to master the skill, years of practice and hard work are required.

Many studies (e.g. Collins \& Parkhurst, 1996) reveal that many students do not express their ideas clearly in their writings. Writing is especially difficult for nonnative speakers because they are expected to create written products that demonstrate mastery of the second language as well as the expression of ideas (Abu-Rass, 2001).

Reasons for creative writing, according to Tompkins (1982), are as follows : 1) to keep amused; 2) to promote artistic expression; 3) to discover the functions and values of writing; 4) to arouse imagination; 5) to clarify thinking; 6) to search for identity; and 7) to learn to read and write.

Multiple simultaneous factors are at work to influence writing achievement including a poor life-style, poor health and inadequate reading habits due to parents' low socio-economic status (Akkaya \& Kirmiz, 2010). One of the most outstanding of them is attitudes to writing. In the following, the term 'attitude' is defined by different researchers.

\section{B. What Is Attitude?}

Attitudes play an important role in forming our world view. They influence our perception of the world around us and determine how we respond to different entities of the world (Jabeen \& Kazim Shah, 2011). The common attitudes of a group of people held for a long time are realized in the form of culture.

As early as 1932, the term attitude was defined by Likert as "an inference which is made on the basis of a complex of beliefs about the attitude object" (cited in Gardner, 1980, p.267). Ajzan (1988, p.4) proposed a different definition of attitudes as "a disposition to respond favorably or unfavorably to an object, person, institution, or event". 
Meanwhile, it was defined by Gardner (1980, p.267) as individuals' entire instinctions and feelings, prejudice or bias, preconceived notions, fears, threats, and convictions about any specified topic".

Likewise, attitude is considered as individuals' psychological states acquired during a certain amount of time due to their experiences McLeod (1991) as well as "a hypothetical construct used to explain the direction and persistence of human behavior" (Baker, 1992, p.10).

\section{Attitudes from the Mentalist and Behaviorist Paradigm}

Attitudes are usually defined along the mentalist and behaviorist paradigm. Drawing on Wenden (1991), many researchers including Jabeen and Kazim Shah (2011), Rahimi and Hassani (2012), Karahan (2007), Al-Tamimi and Shuib (2009), and Musgrove (1999) believe that attitudes have cognitive, affective and behavioral components. The Encyclopedia of Psychology (2004) discusses the attitudinal model, similarly, on the basis of these three factors. The cognitive component involves beliefs or perceptions about the objects or situations related to the attitude. The affective component refers to the feelings and emotions that one has towards an object, 'likes' or 'dislikes', 'with' or 'against'. The behavioral component means that certain attitudes tend to prompt learners to adopt particular learning behaviors. Attitude not only predicts behavioral patterns (Speilberger, 2004), it also triggers various manifestations of behavior (Jabeen \& Kazim Shah, 2011).

Thus, emotions and attitudes are different affective states, although an attitude may bring about an emotional response, as in a student's negative attitude toward writing leads to hatred and apprehension (Musgrove, 1999). As a matter of fact, emotional responses are among the subsets of attitudes and a dominant aspect of attitude .

\section{Language Attitude}

Learning a language is closely related to the attitudes towards the languages (Starks \& Paltridge, 1996). 'Language attitudes', according to the Longman Dictionary of Applied Linguistics (1992), are defined as the attitude which speakers of different languages have towards each others' languages or to their own language.

The relationship between attitude and performance has been viewed as mutual, with each factor affecting the development of the other (Mathewson, 1994). All in all, SLA literature supports a relationship between attitudes towards a language and language achievement (Masgoret \& Gardner, 2003).

Drawing on Gardner and Lambert (1972), Karahan (2007) states that positive language attitudes give learners positive orientation towards learning English, and enhance proficiency as well, and vice versa. This is supported by Brown (2000) who adds the positive attitudes towards the self, the native language as effective factors as well. Furthermore, Karahan (2007) adds what people feel about the speakers of the language being the learned as an effective factor.

According to Dörnyei \& Csizér (2002), positive attitude facilitates foreign language learning while negative attitude acts as a psychological barrier against it. Thus, attitudes, ranging from negative, natural, and positive, determine students' success or failure in their learning. This highlights the important role which positive attitude towards the language being learned plays in learning a second language. Putting it another way, maintaining positive or negative feelings towards a language may bring about difficulty or ease of learning.

\section{E. Writing Attitude}

The relationship between attitude and writing achievement has received rather little attention in TEFL literature (Graham, Berninger \& Fan, 2007). Writing attitude is highly effective on improving or hindering writing achievement (Bartscher, Lawler, Ramirez and Schinault, 2001).

Writing attitude is defined by Graham et al (2007) as "an affective disposition involving how the act of writing makes the author feel, ranging from happy to unhappy." (518) In other words, the more positive attitude students have towards writing, the more energy they spend on the task.

Examining their roots of negative attitudes students have towards writing lessons, Sever (1998) notes that in primary years of education, the way teachers conduct classes and teach writing lessons is important in forming negative or positive impressions regarding writing among students. That is, boring writing classes negatively influence attitudes (Akkaya \& Kirmiz, 2010).

\section{F. Writing Apprehension}

Writing apprehension can be defined as "a general avoidance of writing and of situations perceived by the individual to potentially require some amount of writing accompanied by the potential for evaluation of that writing" (Daly and Miller, 1975).

According to Aikman (1985), negative attitudes toward writing result in predictable behaviors such as delay in completing writing assignments.

\section{G. Related Literature}

Considering the fundamental role played by attitudes in human beings' lives, it is not unexpected to see that attitudinal studies have a long historical background (Oppenheim, 1998). There is a great body of literature regarding attitudinal research on attitudes towards different languages (Marley, 2004, Balcazar, 2003, Levine, 2003; Villa, 2002, 
Malallah, 2000; White, 2002; Bernat and Gvozdenko 2005; Csizér and Dörnyei, 2005; Graham, 2004, to name a few). There is a plethora of research conducted to investigate learners' attitudes towards the English language. Besides, different aspects of language attitudes have been studied such as the relationship between attitudes and language achievement, beliefs about target language use, attitudes towards English-language speakers, the relationship between attitudes towards ideology, and language achievement.

Studies such as Vijchulata and Lee (1985), Sarjit (1993), Benson (1991), Buschenhofen (1998), Arani (2004), Karahan (2007), Qashoa (2006), Al-Quyadi (2002) reconfirmed the importance of identifying learners' motivation and attitudes towards the English language. These studies help the researchers to understand the how to identify learners' motivation by focusing on learners' attitudes (Al-Tamimi \& Shuib, 2009).

\section{THE STUDY}

The subjects of this study were 65 undergraduates at the University of Isfahan, one of the most accredited public universities in Iran. Two different classes consisting of 28 and 37 students were chosen randomly in the spring of 2012.

The participant's ages ranged from 18 to 30 years and they were non-native speakers of English. Among the participants, 24 ones did not know any third language (other than English and Persian). And, the 41 subjects who already knew a third or fourth language were skilled at the language merely in an elementary or intermediate level.

Some of the participants had native-like fluency with English, having studied English since the age of 6 to 9. Others did not have native-like fluency, but they all claimed to be progressing towards the advanced level studiously and diligently. Overall, the age they began to learn English ranged from 6 to 13 years old.

\section{A. Data Collection Instruments and Procedures}

The instrument used to collect the data was a detailed 4-paged open-ended questionnaire. Questionnaires are one of the most commonly used methods for both quantitative and qualitative research. An open-ended question is usually designed to encourage a full, meaningful answer using the subject's own knowledge, opinions or feelings, and is asked where statistical validity is not the main goal.

By and large, questionnaires are considered as a quantitative method for collecting data; however, open-ended descriptive questionnaires can be used in qualitative studies as well. Unlike in a multiple choice question, open-ended questions are unstructured question in which no possible answer is suggested.

\section{B. Data Collection Procedure}

The researcher distributed 65 open-ended questionnaires to two different undergraduate English classes. The participants were required to answer the open-ended questionnaires (adopted from Jabur, 2008) consisting of 36 items to investigate how their identity is formed and shaped by writing in English as a foreign language.

The questionnaire consisted of only open-ended questions to make sure that the participants write as various and deeply detailed explanations as possible. The questionnaire has been already validated by Jabur (2008), though the researcher also adjusted the questionnaire to the new research setting by means of conducting a pilot study on 9 participants beforehand. Based on the analysis and results generated from the answers provided by the pilot study, a more specific set of open-ended questionnaire and interview questions were designed. Besides, before handing out the questionnaires among the participants, the researcher translated the questionnaires from English to Persian to assure the participants' paramount comprehension of what they were exactly asked to write about as well as to assure the subjects' utmost convenience in production and facing the least problem while trying to make themselves understood.

\section{Data Analysis}

Data analysis is the most complicated and most critical aspect of a qualitative research, which aims to find out the categories, relationships and theories based on the participants' view of the topic. Data analysis is the process of examining the collected data by observing, categorizing, and understanding to identify themes and reach conclusions.

\section{Validity}

Keeping in her mind that she will have to explain how she came to the final claims and conclusions from the data, the researcher made an attempt to avoid coding according to what she wanted to find, or putting words into the participants' mouths.

The researcher did her utmost not to impose her bias, narrow-mindedness, presumptions and previous knowledge of the issue and concentrate instead on finding new themes in her data.

\section{E. Research Questions}

1. What are Iranian EFL students' attitudes towards writing in general?

2. Are Iranian EFL students active writers? If yes, in which language?

3. Do Iranian EFL students feel any difference between expressing ideas while writing in English and Persian?

\section{RESULTS AND DISCUSSION}




\section{A. Attitudes toward Writing in General}

There were various answers provided when the participants were asked to write a short paragraph regarding how they felt toward writing in general. Their comments revealed a surprising division among them from liking writing because of its advantages to disliking it for different reasons especially because of its difficulty or being boring.

\section{Writing as a difficult task}

11 participants reported how they considered themselves as bad writers, elaborating that they did not like writing as it was a difficult task. To name a few, Mehran complained that unless he had had studied on the matter beforehand, he was unable to convey his ideas, or put his ideas together and commit them to the paper; thus, he always thought that his readers would be perplexed. Likewise, Sara insisted that although an amusing and interesting task, writing is so intricate for her that after she is done with a paragraph, she feels she is relieved!

Looking through a pessimistic perspective, Masood pointed out that writing has always been a difficult task and will be forever. He added, "When I was in high school and junior high school I used to write compositions which were admired by everyone, but now I don't like writing anymore."

As another participant who mentioned the disadvantages of writing in comparison with other language skills are, Meysam, complaining about the restrictions he faces while writing, said, "I like writing but not as much as I love speaking because following certain rules in writing such as paragraphing, punctuation, etc. should be taken into consideration which all in all make a hurdle in writing." He added that the essential role of writing in human's life cannot be denied; the only problem is that writing properly and satisfactorily is difficult.

Being a time-consuming task was another reason Mohammad provided for not taking on writing as a daily activity, which he attributed to the sensitivity he had in choosing suitable words and structures.

\section{Writing as an enjoyable task}

While 11 participants addressed writing as a difficult and time-consuming, and as a result not enjoyable activity, 13 participants reported to love and enjoy writing for different reasons.

For example, Maryam who said she really loved writing only when she was free and in the mood, stated, "If I am interested in the subject, the result will turn out to be good. My readers, in my opinion, can comprehend what I mean in my writings."

In a much similar way, Homa, discussing why she liked writing, pointed out, "I enjoy it because whenever I write, I suppose that the entire world is my addressee, rather than a certain person." Thus, imagination, as the distinctive feature of writing is presented as an important factor to use writing. This was agreed by Mona saying that the reason why she really liked writing was that it increases the innovation of our mind in addition to the imagination power.

Having loved writing since his childhood when he used to writing stories in Persian, Mohammad stated that "It is really nice to have a habit to write down one's feelings regularly in different stages of life mainly because when I read them later on, I really enjoy it, feeling nostalgically."

Regarding it as a task one can start at the very beginning of language learning, Sima commented, "I love writing because from the very beginning of language learning one can take it up. I used to think that one should be quite master in a language to start writing in it but now I know that it is not so."

Stressing the role of encouragement in increasing one's interest in writing, Parvin reported that "I remember the first time that I wrote in English for which my father gave me a gift. This was a big encouragement for me to love writing. I really like writing and I do with a lot. The texts I have written have been posted online so far and generally have had interesting feedbacks." For Parvin, receiving feedbacks from different people, which all in all helps the writer promote the quality of his or her work, is mentioned as another reason to be interested in writing. Parvin said that she really looks forward to receiving her readers' comments on her writings as soon as she posts a new writing on her weblog.

Nonetheless, being interested in writing was not only stated by those who were active writers. This was demonstrated by Mahin who although has not enthusiastically been involved in writing in a serious manner, she likes to be able to use her pen to impress her readers and direct them towards a better world.

\section{Writing as a tool for releasing excitement}

11 out of 65 participants explained that writing, one of the basic needs of human beings, is a tool for releasing ourselves, sending out all daily tensions, concerns and negative feelings.

Mina, for example, pointed out, "When there's no one to listen to what I want to say, I start writing. My pen and paper are my friends in loneliness." This was supported by Saeed who added that our feelings cannot be captivated in our hearts; they should be released through writing. Likewise, Azin stated, "Writing, for me, is like washing the dishes; I am released through writing." Therefore, writing is considered as one of the essential fundamentals for human being's daily life in terms of excitement release. Fatemeh commented that her heart urges her to write only whenever she is experiencing the apex of happiness or sadness. Sometimes when she starts to write especially when she wants to talk about her feelings she gets so much brainstormed that ideas jump out of her mind automatically.

Maryam and Aida even saw writing as a must for mental relaxation, believing that writing about what is going on in our mind is really important for our mental health, because there are sometimes some words we can't let others know face to face. Therefore it is better to write them down, so that we feel enough tranquility. Aida added: "For me, writing is a way to release my thoughts and to free my soul. It is the best way to tranquilize yourself when you don't like or you're unable to say what is in your heart." 
Hadi, who considers writing essential in his regular activities pointed out, "Sometimes I feel I am so much in need of writing that I'd go for it unintentionally. I have always been encouraged for my good compositions throughout my school time. I don't know why, but it seems as if whenever my hand finds a pen or something around, it starts writing what is going on in my head, without letting me know it."

\section{Writing as a tool for freedom of speech}

Freedom of speech was another reason why writing was favored by some subjects including Omid who reported that principally he enjoys writing because it is only during writing that he is able to think independently and free from others. Writing in any languages especially in Persian gives me freedom, because there are many things tongue cannot talk about but pen can write about. Thus, regardless of the language in which writing is encoded, it is considered as a more liberal way to convey the thoughts and feelings without being criticized directly.

According to Matin, another participant who believed in liberal aspect of writing, writing is a way to discuss in detail and directly what we cannot talk about openly for others. Thus, he sees writing as the most liberalist activity available to him.

Laleh adds that in writing, we are allowed to express our feelings in any way we desire. Sometimes, we like to write ambiguously and sometimes directly. Therefore, we are not restricted, nor do we fear people's criticism. She went on to say that today, writing our feelings is much easier than talking about them face to face; and the emergence of SMS proves this. SMS has been a very useful tool to express our words whenever we feel unable to say them directly.

However, Arezoo, who seems to have suffered from lack of self confidence feared, that her writings would the laughed at, if read, explained:

"When I write I can express myself more beautifully than when I speak. I really like to commit the very moments of my life to the paper but I always avoid it because I am afraid someone might read it and make fun of it."

Thus, two opposite opinions regarding writing is observed; one of which considered writing as a tool for expressing ourselves freely while the other complained that writing limits us as it is exposed to be read by everyone. What this may suggest is that writing is a skill which has contradictory dimensions.

\section{Writing as a method to improve the speaking skills}

Writing, in a sense, can be considered as a type of careful and cautious speaking which is documented. Accordingly, it plays an important role in improving one's power of speaking. The mistakes one makes while speaking can be avoided when one commits his or her ideas to the paper.

6 students commented that they are interested in writing and that they really aim to increase this skill in both Persian and English as it helped improve their speaking skills simultaneously. Shadi, for example, pointed out, "My writing is of good quality, although I want to promote it. I always decide to start writing regularly from this very tonight, but the writing activity seems so boring to me that actually I never start." Similarly, Ali notes that for a university student writing is a superior way to express one's feelings and thoughts, because it indirectly promotes one's ability to give a lecture.

\section{Other advantages of writing}

Believing that in order to promote one's writing skill, we should keep on writing, many of the participants stated that the writing skill is actually a technique which all of us, more or less, have the ability to promote. Besides, a person can find some topics he or she is interested in.

Explaining different advantages of writing, Amirali regarded writing as a way to preserve scientific findings or literary works: "if not committed to paper, scientific findings or literary works will be forgotten and vanished."

Ramin and Hadi, both of whom have recently started to write their diaries in their journals in Persian and sometimes in English, emphasized that diary writing has not only affected their writing quality, but also it has made them think about and improve their daily acts and behaviors.

The following, which is a comment given by Behnaz highlights an interesting use of writing:

"Writing is the best way to express one's feelings both personally and socially. When I want to talk to my daughter, as she is too young to understand, I'd rather write them down so that she'll read them in the future."

Here, writing is used as a device to connect the present to future; to make a link and remove the age gap; and to communicate with people not present now, or not able to understand our words at the moment.

Also, there was another attention-grabbing use of writing by one of the students:

"Writing plays an important role in my life. Even it was through writing that I got familiar with my espouse, which is the biggest gift that writing has given to me. I daresay that writing has changed the whole direction of my life."

Lastly, 3 participants said they had no idea about writing or left the space missing.

\section{B. Being or Not Being Active Writers}

The responses provided by the participants when asked whether they were active writers, and if yes in which language, fell into two categories:

The first group consisting of 20 participants claimed that they are not active writers. The second group including 45 students claimed to be active writers, actively writing their diary in their journals or weblogs. These 45 participants could be classified into three groups: 
First, 7 participants said that they usually write in English. Second, 26 ones said that they are active writers in Persian. Third, there were 12 participants who stated that they write both in Persian and English depending on the setting, their mood, and the topic.

\section{Any Difference between Expressing Ideas in English and Persian}

The second question aimed to explore whether the students' writing in English differed from their Persian ones. If yes, then what exactly the differences were.

1. no differences between expressing ideas in English and Persian

20 participants, out 65, denied any difference in their writing in English and Persian, noting that there was little difference (if any), because when a person is writing, although in different languages, his thoughts, feelings and beliefs are constant and there is only a shift in the language.

\section{2. differences between expressing ideas in English and Persian}

40 participants responded "yes" to the question whether their Persian writing was different from their English ones, adding that, most obviously, since two absolutely different language systems are involved, there must be some differences in terms of grammatical rules as well as the addressees' view points, cultural values.

Besides, being non-native speakers, participants claimed to have two different proficiency levels; one language is their mother tongue and the other is a foreign language. English and Persian are two completely different linguistic systems; hence writing in them has to be different as well. For example, Soheil explained:

"Being a native speaker in Persian, it goes without saying that I write in Persian without needing to look up any words in dictionaries, but in English I have to do so continually which makes me tired of writing. This is one of the main differences between my writing in English and Persian which I usually encounter."

Some participants explained that they are more proficient in Persian obviously, so they feel they write better in English, or they are too weak in English writing, therefore they prefer Persian when they are writing as they are more at ease in Persian.

Mina and Aida, for example, pointed out that the only difference in their writing in English and Persian is because of their full proficiency in Persian, which leads to having more words available and facing less grammatical difficulties in their mother tongue: "There are a lot of differences; obviously my Persian writing is more fluent. As Persian is my mother tongue, I am more fluent when writing in Persian."

Complaining about the mismatch between the proficiency levels, Matin and Fatemeh commented that in writing in English the whole effort focuses on avoiding grammatical or lexical mistakes, but in Persian the topic is the main focus. Matin said:

"In writing in Persian we have a wider range of vocabulary at our service and we have almost no problem in terms of grammar. Besides, not being familiar with English context, we usually encounter problems in English. Sometimes we get so involved in grammatical and lexical accuracy in our writings that we forget about the main idea we were to convey."

\subsection{Shorter sentences and shorter writings in English}

A few students indicated that their English writings have shorter sentences, while their sentences in Persian are longer. As a result, their writings are shorter in English. Besides, it was mentioned that using compound and complex sentences in English is somehow problematic for some of the participants.

\subsection{Writing more directly in English}

Peyman and Masood stated that in writing in English we can be more frank and explicit, in contrary to the Persian one which goes indirectly. They feel that they write more directly, openly and outspokenly in English, while Persian writing requires more ambiguity and indirect conveying as meaning. Therefore one may feel less limited while writing in English.

\subsection{Writing more emotionally in English}

Mahin, as one of the participants who claimed that there are differences between expressing her ideas in English and Persian, believes that in writing in English, feelings are more involved, leading to a more emotional outcome. Likewise, Sanaz commented that she writes more emotionally and simply in English.

\subsection{Feeling someone else or imagining oneself abroad while writing in English}

Three students, surprisingly, when asked to compare their writings in Persian and English, gave their responses which were the most outstanding for this question. They explained that when they write in Persian, they feel that they can express themselves comfortably and that they are themselves: "I am not myself when I write in English; my writing in English has some kind of artificial feelings in it."

In the same manner, Sima, commented that her writing in English involved imagining herself abroad, in the country which the language is spoken.

\subsection{Linguistically richer and more elaborative outcomes in Persian}

Ramin, one of the participants who considered his English writing totally different from his Persian ones, advocated the quality of his English writings, explaining: "my English writing outcomes has been richer than my Persian ones, which might be owing to the fact that I've never done my Persian writings seriously." This was agreed by Iman who said that he is much more at ease when he writes in English, because discussing the topics in detail is more possible and 
easier in English. In sharp contrast with this comment was Ali's, who asserted that he could elaborate on the issue in Persian more than English because he had wider background knowledge about the Persian topics.

As another supporter, Omid believed that the liveliness in his Persian writings was absent in the English ones.

\subsection{More respectful words in Persian}

As one of the supporters of writing in Persian, Mahin discussed how her Persian writings were different from her English ones, noting that she can use more respectful words in Persian. For example when she wants to write a letter, there are a wider range of words to use as a greeting to show respect.

In the end, there were three students who had left the questions missing and one who refused to compare them as he believed that the two languages are not related to one another, so they are not comparable.

\section{CONCLUSION}

The obvious conclusions to be drawn from the above-mentioned responses are three-folded:

Firstly, the data show that the participants were mostly active writers. More importantly, among those who write actively, most of them write in Persian; some of them write both in Persian and English depending on the setting, their mood, and the topic; and, a few of them only write in English.

Second, while the first group of participants reported that writing is a difficult, boring and time-consuming task, the second believed that writing is an enjoyable task, as it involves imagination and innovation of mind on one hand, and receiving feedbacks and comments on the other hand. The third group were those who explained that writing is one of the basic needs of human beings, or more specifically it is a tool for releasing excitement, through which one sends out all daily tensions, concerns and negative feelings, and gains enough tranquility. The fourth consisted of those who considered writing as a tool for freedom of speech, explaining that there are many things we cannot talk about but we can write about, without fear of being criticized directly. The emergence of SMS proves this assertion. The fifth group of participants considered writing as a way to improve the speaking skill, because they consider writing, as a type of careful and cautious speaking, and accordingly the mistakes one makes while speaking can be avoided when committed to paper. Finally, some participants mentioned other advantages, for example writing is a way to prevent scientific findings or literary works from being forgotten; writing, particularly journal writing, improves the quality of daily acts; and writing is used as a device to connect the present to future; to make a link between different generations and remove the age gap. What the list claims is that writing is a multi-dimensional language skill which language learners can take on for various purposes. The different and sometimes contrary aspects of writing including being difficult, boring and time-consuming; enjoyable; a tool for releasing excitement; a tool for freedom of speech; a way to improve the speaking skill; a way to prevent scientific findings or literary works from being forgotten; a way to improves the quality of daily acts; and a device to connect the present to future all in all suggests the intricacy of this language skill.

Finally, most of the Iranian English-major students feel that expressing ideas while writing in English is different from writing in Persian. The differences, mainly caused by proficiency mismatch between the two languages, include shorter sentences in English; more directness in English; more emotions involved in English; feeling someone else or imagining themselves abroad in English; linguistically richer and more elaborative outcomes in Persian; and more respectful words in Persian.

\section{REFERENCES}

[1] Abu Ras, R. (2001). Integrating reading and writing for effective language teaching, English Teaching Forum, 39(1), 30-39.

[2] Aikman, C. (1985). Writing anxiety: Barrier to success. Paper presented at the National Adult Education Conference, Milwaukee, WI.

[3] Ajzan, I. (1988). Attitudes, personality and behaviour. Chicago: Dorsey Press.

[4] Akkaya N. and Kirmiz F. S. (2010). Relationship between attitudes to reading and time allotted to writing in primary education, Procedia Social and Behavioral Sciences, 4742-4746.

[5] Al-Quyadi, A. (2000). Psycho-sociological variables in the learning of English in Yemen. Ph. D thesis, Bhagalpur University.

[6] Al-Tamimi \& Shuib. (2009). Motivation And Attitudes Towards Learning English: A Study Of Petroleum Engineering Undergraduates At Hadhramout University Of Sciences And Technology, GEMA Online Journal of Language Studies 29 Volume 9(2), 29-55.

[7] Arani, J. (2004). Issues of learning EMP at university: An analysis of students' perspectives. Karan's Linguistics Issues. http://www3.telus.net/linguisticsissues/emp.

[8] Baker, C. (1992). Attitudes and language. Clevedon: Multilingual Matters.

[9] Balcazar, I.H. (2003). Language Shift and Language Attitudes of Kaqchikel Maya Adolescents. Paper presented at the 4th International Symposium on Bilingualism, Arizona State University.

[10] Bartscher, M. A., Lawler, K.E., Ramirez, A.J. \& Schinault, K.S. (2001). Improving student's writing ability through journals and creative writing exercises. Master of Arts action research project reports, Saint Xavier University, Chicago.

[11] Benson, M. J. (1991). Attitudes and motivation towards English: a survey of Japanese freshmen. RELC Journal, 22(1), 34-48.

[12] Bernat, E. and Gvozdenko, I. (2005). Beliefs about language learning: Current knowledge, pedagogical implications, and new research directions, TESL EJ, Vol.9, No.1, pp. 1-21.

[13] Buschenhofen, P. (1998). English language attitudes of Final-Year High School and First-Year university students in Papua New Guinea. Asian Journal of English Language Teaching, 8, 93-116. 
[14] Collins, N. D., \& Cross, T. L. (1993). Teaching the writing process to gifted and talented students. Gifted Child Today, 16(3), $22-23$.

[15] Csizér, K. and dörnyei, Z. The internal structure of language learning motivation and its relationship with language choice and learning effort, The Modern Language Journal, 89, i, (2005), pp. 19-36.

[16] Dally, J. \& Miller, M. (1975). The empirical development of an instrument of writing apprehension. Research in the Teaching of English, 9(4), 272-289.

[17] Dörnyei, Z. and Csizér, K. (2002). Some dynamics of language attitudes and motivation: Results of a longitudinal national survey. Applied Linguistics, 23, 421-462.

[18] Gardner, R. (1980). On the validity of affective variables in second language acquisition: conceptual and statistical considerations. Language Learning, 30 (2), 255-270.

[19] Gardner, R. C. and Lambert, W. (1972). Attitudes and motivation in second language learning. Rowley, Ma: Newbury House.

[20] Graham S., Berninger V. \& Fan W., (2007), The structural relationship between writing attitude and writing achievement in first and third grade students, Contemporary Educational Psychology 32, 516-536.

[21] Graham, S., Harris, K.R. \& Mason, L. (2005). Improving the writing performance, knowledge, and self-efficacy of struggling young writers: The effects of self-regulated strategy development, Contemporary Educational Psychology, 30 (2), 207-241.

[22] Graham, S.J. (2004). 'Giving up on modern foreign languages? Students' perceptions of learning French', The Modern Language Journal, 88, pp.171-191.

[23] Hamed Jahin J. \& Wafa Idrees M. (2012). EFL Major Student Teachers' Writing Proficiency and Attitudes Towards Learning English, Journal of Taibah University, KSA, 9-72.

[24] Jabeen F. \& Kazim Shah S. (2011). The Role of Culture in ELT: Learners' Attitude towards the Teaching of Target Language Culture, European Journal of Social Sciences - Volume 23, Number 4, 604-613.

[25] Levine, G.S. (2003). Student and instructor beliefs and attitudes about target language use, first language use and anxiety: Report of a questionnaire study, The Modern Language Journal, 87, 3, pp. 343-364.

[26] Malallah, S. (2000). English in an Arabic environment: Current attitudes to English among Kuwait university students, International Journal of Bilingual Education and Bilingualism, Vol.3, No.1, pp.19-43.

[27] Marley, D. (2004). Language attitudes in Morocco following recent changes in language policy, Language Policy, 3, pp. $25-46$.

[28] Masgoret, A. M. and Gardner, R.C. (2003). Attitudes, motivation, and second language learning. A meta-analysis of studies conducted by Gardner and associates. Language Learning, 53, 123-163.

[29] Mathewson, G. (1994). Model of attitude influence upon reading and learning to read. In R. Ruddell, M. Ruddell, \& H. Singer (Eds.), Theoretical models and processes of reading (4th ed., pp. 1131-1161). Newark, DE: International Reading Association.

[30] McLeod, S. H. (1991). The affective domain and the writing process: working definitions. Journal of advanced composition, 11. 95-105.

[31] Qashoa, S. (2006). Motivation among learners of English in the secondary schools in the eastern coast of the UAE. M.A thesis, British University in Dubai.

[32] Sarjit Kaur. (1993). Analysis of the English language needs of consultants at NCVC. M.A thesis, University of South Australia.

[33] Sever, S. (2004). Türkçe ö retimi ve tam ö renme [Turkish instruction and whole learning]. Ankara: An Yay nc 1 k.

[34] Starks, D. and paltridge, B. (1996). A note on using sociolinguistic methods to study non-native attitudes towards English, World Englishes, 15 (2), pp. 217-224.

[35] Tompkins, G. E. (1982). Seven Reasons Why Children Should Write Stories. Language Arts, 59(7), 718-21. [EJ 269 736].

[36] Vijchulata, B., \& Lee, G. (1985). A survey of students' motivation for learning English. RELC Journal, 16 (1), 68-81.

[37] Villa, D.J. (2002). The sanitizing of U.S. Spanish in academia, Foreign Language Annals, 35, 2, pp. 222-30.

[38] Wall, D. (1981). A pre-sessional academic writing course for postgraduate students in economics. Practical Papers in English Language Education, vol. 4, 34-105, United Kingdom: University of Lancaster.

[39] Wenden A. (1991). Learner Strategies for Learner Autonomy, Englewood Cliffs, N. J: Prentice Hall.

[40] White, C.M. (2002). Language authenticity and identity: Indigenous Fijian students and language use in schools, Language, Culture and Curriculum. 15, 1, pp. 16-29.

Razieh Gholaminejad, an MA student of TEFL at the Faculty of Foreign Languages, University of Isfahan.

\begin{abstract}
Ahmad Moinzadeh is currently assistant professor of linguistics at the department of English, faculty of foreign languages, university of Isfahan, Isfahan, Iran. He has instructed BA, MA and PhD courses at this department for many years. His main areas of research are syntax, comparative / contrastive linguistics, morphology and language acquisition he holds a PhD degree in linguistics, an MA degree in Linguistics and a BA degree on English language and literature.
\end{abstract}

Manijeh Youhanaee, associate lecturer, holds a PhD in language and linguistics from the University of Essex. She is currently the head of the English Department at University of Isfahan. She has presented MA and PhD courses in linguistics, Generative Grammar and second language acquisition. Her areas of interest include syntactic theory, acquisition of L2 \& L3 syntax, L2 acquisition of word order versus morphological markers and properties of L2 lexical attrition.

Hamidreza Ghobadirad, an MA student of TEFL at the Faculty of Foreign Languages, University of Isfahan, has been teaching English for 12 years to both the children and adults. Apart from teaching in Sadr, Sokhansara and Gooyesh, he was the manager of Kish institute for five years. 